\title{
Phase Behavior and Physical Parameters of Natural Gas Mixture with $\mathrm{CO}_{2}$
}

\author{
Dali Hou, ${ }^{1,2,3}$ Hucheng Deng, ${ }^{1,2}$ Hao Zhang, ${ }^{1,2}$ Kai Li, ${ }^{1,2}$ Lei Sun, ${ }^{3}$ and Yi Pan ${ }^{3}$ \\ ${ }^{1}$ School of Energy Resources, Chengdu University of Technology, Chengdu, Sichuan 610059, China \\ ${ }^{2}$ The State Key Laboratory of Oil and Gas Reservoir Geology and Exploitation, Chengdu University of Technology, Chengdu, \\ Sichuan 610059, China \\ ${ }^{3}$ The State Key Laboratory of Oil and Gas Reservoir Geology and Exploitation Engineering, Southwest Petroleum University, \\ Xindu Avenue No. 8, Chengdu, Sichuan 610500, China
}

Correspondence should be addressed to Dali Hou; houdali08@163.com

Received 3 January 2015; Revised 28 March 2015; Accepted 4 April 2015

Academic Editor: Christophe Coquelet

Copyright (c) 2015 Dali Hou et al. This is an open access article distributed under the Creative Commons Attribution License, which permits unrestricted use, distribution, and reproduction in any medium, provided the original work is properly cited.

\begin{abstract}
The two-flash experiment, constant composition expansion experiment, saturation pressure measurement experiment, and phase transition observation experiment from well bottom hole to well head of four high $\mathrm{CO}_{2}$ content natural gas samples were carried out by using the JEFRI-PVT apparatus made from DBR Company of Canada. The experimental results show that in the four high $\mathrm{CO}_{2}$ content gas samples no phase transitions will take place at temperatures greater than $35^{\circ} \mathrm{C}$. In the gas-liquid two-phase region, saturation pressures, critical pressure, critical temperature, and an integrated $P$ - $T$ phase diagram of different $\mathrm{CO}_{2}$ content natural gases are calculated by using the modified PR equation of state and modified ( $\mathrm{T}$ ) equation proposed by Saffari. The deviations between the saturation pressure calculated by using the model proposed in this study and experimental measured saturation pressure are very small; the average relative error is only $2.86 \%$. Thus, the model can be used to predict the phase equilibrium parameters of high $\mathrm{CO}_{2}$ content natural gas.
\end{abstract}

\section{Introduction}

With the increasing demand of $\mathrm{CO}_{2}$ resource, exploration and development of high $\mathrm{CO}_{2}$ content gas reservoirs are becoming one part of the future oil-gas strategy [1]. Currently, the discovered high $\mathrm{CO}_{2}$ content gas reservoirs in the world are mainly distributed over the Pacific, such as Japan, Indonesia, New Zealand, Philippines, Vietnam, Thailand, Malaysia, Australia, Mexico, America, and Canada [2-5]. Twenty-eight high $\mathrm{CO}_{2}$ content gas reservoirs have been discovered in China and they are mainly distributed in oil-bearing basins in the east of China, in which the high $\mathrm{CO}_{2}$ content natural gas reserve is $20000 \times 10^{8} \mathrm{~m}^{3}$ in Songliao basin [6]. Furthermore, $\mathrm{CO}_{2}$ content in Changling, Gudian, Honggang, Shengping, Fangshen, and other gas reservoirs in Jilin oilfield of Songliao basin can even range from $20 \mathrm{~mol} \%$ to $90 \mathrm{~mol} \%$ [7-9]. High $\mathrm{CO}_{2}$ content natural gas reservoir is very special and development is very difficult, which mainly reflects in the variation of fluid phase behavior. The research of some scholars at home and abroad focuses on the physical parameters and development index of the $\mathrm{CO}_{2}$ contents in natural gas [7, 914], but seldom focus is directed on the phase behavior of natural gases with high $\mathrm{CO}_{2}$ content and the phase behavior of natural gas with high $\mathrm{CO}_{2}$ content is not entirely clear at present [15-19]. Thus, it is one of basic research topics on the experimental measured saturation pressure to determine whether any phase transitions in natural gases with high $\mathrm{CO}_{2}$ content take place from formation to well head and the physical parameters of high $\mathrm{CO}_{2}$ content natural gases for high-efficient developing the gas reservoirs with high $\mathrm{CO}_{2}$ content.

It is revealed in this paper whether any phase transition in high $\mathrm{CO}_{2}$ content natural gases takes place in the exploitation process. The saturation pressures of different $\mathrm{CO}_{2}$ content in natural gases at different temperatures are measured by using the DBR-PVT apparatus, and the saturation pressures, critical 
pressures, critical temperatures, and an integrated $P-T$ phase diagram of different $\mathrm{CO}_{2}$ content natural gases are calculated by using the modified PR equation of state and modified $\alpha(T)$ equation proposed by Saffari. And the deviations between the saturation pressure calculated by using the model proposed in this paper and experimental measured saturation pressure are analyzed. Also revealed in this paper is the influence of different $\mathrm{CO}_{2}$ content in natural gases on the $P-T$ phase diagrams and critical points. Furthermore, the variation law and affecting factors of the physical parameters, such as relative volume, $Z$-factor, formation volume factor, and density of high $\mathrm{CO}_{2}$ content natural gases are discussed in this paper.

\section{Theories}

By modifying the attractive term in the Redlick-Kwong equation of state, Peng and Robinson were able to enhance the model prediction of experimental data. Since its inception, Peng-Robinson EOS has been widely used to estimate thermodynamic properties for hydrocarbon systems. It reads $[20,21]$ as

$$
P=\frac{R T}{v-b}-\frac{a(T)}{v(v+b)+b(v-b)},
$$

where $P$ is pressure, $T$ is temperature, $v$ is the molar volume, $R$ is the gas constant, and $a(T)$ and $b$ are the parameters of the EOS. At constant $P$ and $T$, the equation will take the form of a cubic equation in $v$ and can be solved for $v$ using any standard analytical or numerical technique [22]. The limitations on critical point lead to the following relations for the PR-EOS parameters [20]:

$$
\begin{aligned}
a(T) & =a\left(T_{c}\right) \alpha(T), \\
a\left(T_{c}\right) & =\frac{0.45724 R^{2} T_{c}^{2}}{P_{c}}, \\
b & =0.0778 \frac{R T_{c}}{P_{c}},
\end{aligned}
$$

where subscript $c$ indicates critical property and $\alpha(T)$ is temperature dependent. In this work, we use the new $\alpha$ function proposed by Saffari, which is written as [23]

$$
\begin{aligned}
\alpha(T) & =\exp \left[k_{1} T_{r}+k_{2} \ln T_{r}+k_{3}\left(1-T_{r}^{1 / 2}\right)\right], \\
T_{r} & =\frac{T}{T_{c}} .
\end{aligned}
$$

The new $\alpha$-functions proposed are exponential functions, each with three adjustable parameters $k_{1}, k_{2}$, and $k_{3}$. Since the adjustable parameters determine attractive intermolecular interactions in a pure component system, the values of $k_{i}$ are compound-specific and should be optimized for each pure component. In this work, we determine the optimum values of pure component parameters by minimizing the error of vapor pressure predicted by using the modified PR equation of state and modified $\alpha(T)$ equation proposed by Saffari with

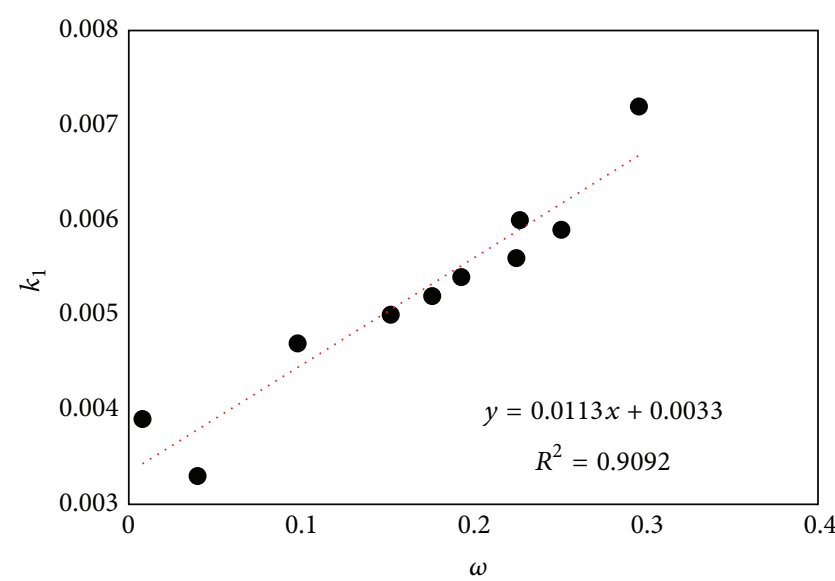

- Fitted parameters Liner (fitted parameters)

FIGURE 1: Linear trend of fitted parameter $k_{1}$ of the $\alpha$-function equation (3).

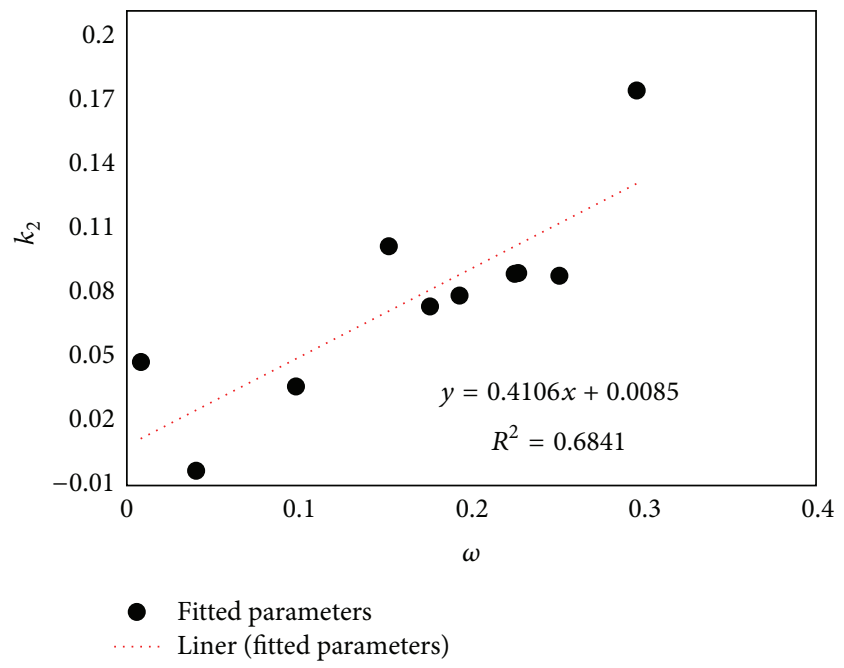

FIGURE 2: Linear trend of fitted parameter $k_{2}$ of the $\alpha$-function equation (3).

respect to the experimental values in the temperature range from triple point to critical point [23].

And we use the individually optimized parameters of pure components for the new $\alpha$-function proposed in this work (3) to develop generalized equations in terms of the acentric factor $\omega$. Pure component constants, including critical properties, and vapor pressure data are obtained from Poling et al. [24], Yaws [25], and Smith and Srivastava [26]. The adjustable parameters of the new $\alpha$-function proposed by Saffari have been fitted to experimental vapor pressure data, given in Table 1.

And then, the parameters $k_{1}, k_{2}$, and $k_{3}$ are generalized as a function of acentric factor $\omega$. Acentric factor of a pure component is obtained from Poling et al. [24]. Figures 1-3 show the trend of fitted parameters presented in Table 1 versus the acentric factor, as well as a linear fit and the $R$-squared. 
TABLE 1: Optimized parameters of the new $\alpha$-function proposed by Saffari (3).

\begin{tabular}{lcccc}
\hline Substance & $T_{r}$ range & \multicolumn{2}{c}{ Optimized parameters } \\
& & $k_{1}$ & $k_{2}$ \\
\hline $\mathrm{CO}_{2}$ & $0.72-1$ & 0.0056 & 0.0881 & 1.4928 \\
$\mathrm{~N}_{2}$ & $0.52-1$ & 0.0033 & -0.0031 & 0.0473 \\
methane & $0.48-1$ & 0.0039 & 0.0359 & 0.8514 \\
ethane & $0.30-1$ & 0.0047 & 0.1010 & 1.0638 \\
propane & $0.26-1$ & 0.0050 & 0.0730 & 1.3640 \\
$i$-butane & $0.28-1$ & 0.0052 & 0.0780 & 1.4200 \\
$n$-butane & $0.33-1$ & 0.0054 & 0.0885 & 1.5626 \\
$i$-pentane & $0.25-1$ & 0.0060 & 0.0872 & 1.5624 \\
$n$-pentane & $0.31-1$ & 0.0059 & 0.1731 \\
hexane & $0.36-1$ & 0.0072 & & 1.8759 \\
\hline
\end{tabular}

TABLE 2: Composition of various gas mixtures and the critical properties of the related component.

\begin{tabular}{lccccccc}
\hline Components & $\begin{array}{c}\text { Gas1 } \\
(\mathrm{mol} \%)\end{array}$ & $\begin{array}{c}\text { YP9 } \\
(\mathrm{mol} \%)\end{array}$ & $\begin{array}{c}\text { Gas2 } \\
(\mathrm{mol} \%)\end{array}$ & $\begin{array}{c}\text { Gas3 } \\
(\mathrm{mol} \%)\end{array}$ & $\begin{array}{c}P_{c} \\
(\mathrm{MPa})\end{array}$ & $\begin{array}{c}T_{c} \\
(\mathrm{~K})\end{array}$ \\
\hline $\mathrm{CO}_{2}$ & 10.045 & 21.746 & 55.535 & 75.323 & 7.376 & 304.2 \\
$\mathrm{~N}_{2}$ & 1.474 & 2.71 & 2.056 & 0.971 & 3.394 & 126.2 \\
$\mathrm{C}_{1}$ & 84.718 & 73.604 & 40.891 & 23.014 & 4.600 & 190.6 \\
$\mathrm{C}_{2}$ & 2.973 & 1.127 & 0.941 & 0.422 & 4.884 & 305.4 \\
$\mathrm{C}_{3}$ & 0.532 & 0.492 & 0.235 & 0.092 & 4.246 & 369.8 \\
$i \mathrm{C}_{4}$ & 0.064 & 0.006 & 0.299 & 0.034 & 3.640 & 0.040 \\
$n \mathrm{C}_{4}$ & 0.058 & 0.301 & 0.004 & 0.042 & 3.800 & 408.1 \\
$i \mathrm{C}_{5}$ & 0.026 & 0.003 & 0.005 & 0.047 & 3.384 & 0.152 \\
$n \mathrm{C}_{5}$ & 0.052 & 0.005 & 0.003 & 0.033 & 3.374 & 460.4 \\
$\mathrm{C}_{6}$ & 0.058 & 0.006 & 0.031 & 0.022 & 2.969 & 0.176 \\
\hline
\end{tabular}

Note: gas sample with $\mathrm{CO}_{2}$ content of $10.045 \mathrm{~mol} \%$ is made from YP9 and dry natural gas, and gas sample with $\mathrm{CO}_{2}$ content of $55.535 \mathrm{~mol} \%$ or $75.323 \mathrm{~mol} \%$ is made from YP9 and pure industrial carbon dioxide (purity > 99.99\%).

Consequently, the final form of new $\alpha$-function with the generalized parameters for natural gas components can be written as

$$
\begin{aligned}
\alpha(T) & =\exp \left[k_{1} T_{r}+k_{2} \ln T_{r}+k_{3}\left(1-T_{r}^{1 / 2}\right)\right], \\
k_{1} & =0.0113 \omega+0.0033, \\
k_{2} & =0.4106 \omega-0.0085, \\
k_{3} & =3.541 \omega+0.7532 .
\end{aligned}
$$

Extending PR-EOS to mixtures requires replacement of coefficients $a$ and $b$ by the following van der Waals composition-dependent mixing rules [20]:

$$
\begin{aligned}
& a=\sum_{i}^{n} \sum_{j}^{n} x_{i} x_{j} a_{i j}, \\
& b=\sum_{j}^{n} x_{i} b_{i} .
\end{aligned}
$$

The unlike-interaction parameter, $a_{i j}$, formed between component $i$ and component $j$, can be related to the pure components parameter with an extra fitting coefficient $\left(k_{i j}\right)$ known as the coupling parameter:

$$
a_{i j}=\left(1-k_{i j}\right)\left(a_{i} a_{j}\right)^{1 / 2} .
$$

\section{Experiments}

3.1. Sample. Experimental gas samples were divided into 4 groups: one group was directly taken from surface separator of YP9 well in Jilin gas field, and the other three groups (Gas1, Gas2, and Gas3) were made from YP9 dry natural gas and pure industrial carbon dioxide (purity > 99.99\%). The detailed synthetic process refers to SY/T6434-2000 [27]. The initial formation pressure and formation temperature of YP9 well are, respectively, $42.34 \mathrm{MPa}$ and $127.5^{\circ} \mathrm{C}$. The components of four groups of gas samples were analyzed by using HP-6890 gas chromatography and Shimadzu GC14A gas chromatography. The results are shown in Table 2. The critical pressure and temperature $[28,29]$ of the pure components which are normally presented in natural gas are also listed in Table 2. The contents of $\mathrm{CO}_{2}$ in YP9 well, Gas1, Gas2, and Gas3 are, respectively, $21.746 \mathrm{~mol} \%, 10.045 \mathrm{~mol} \%$, $55.535 \mathrm{~mol} \%$, and $75.323 \mathrm{~mol} \%$. The $\mathrm{CO}_{2}$ content in natural gas being more than $10 \mathrm{~mol} \%$ is usually called the high $\mathrm{CO}_{2}$ 


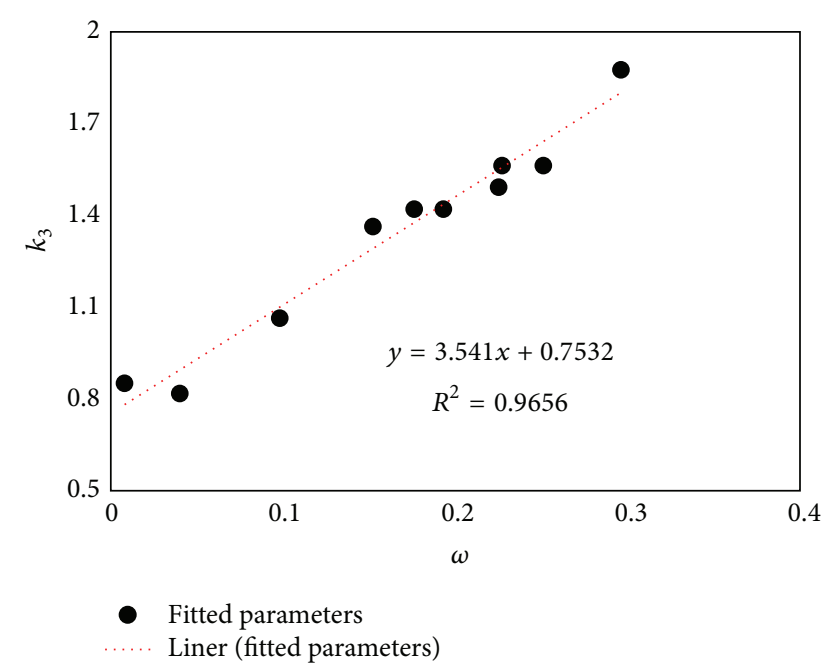

FIGURE 3: Linear trend of fitted parameter $k_{3}$ of the $\alpha$-function equation (3).

content natural gas [30]. Thus, The four groups of gas samples are all the high $\mathrm{CO}_{2}$ content gas samples.

3.2. Apparatus. The experimental facility is a mercury-free high pressure PVT system made by the DBR Company, Canada. A schematic diagram of the corresponding apparatus is given in Figure 4. It is mainly characterized by the visual observation of experimental phenomena and the specially designed piston in the PVT cell that allows us to precisely measure even minute liquid. The system is mainly made up of a PVT cell, thermostatic air bath, pressure sensor, temperature sensor, flash separator, electronic balance, gasometer, gas chromatography, sample container, automatic pump, and operation control system. Sample container is made from sapphire glass.

The volume of fluid in the PVT cell can be calculated by the internal cross-sectional area of sapphire glass cylinder multiplied by the height of the fluid, which was measured by the grating altimeter.

The physical parameters of main parts are as follows.

PVT cells: maximal working pressure is $70 \mathrm{MPa}$, the highest operating temperature is $200^{\circ} \mathrm{C}$, the lowest operating temperature is $-100^{\circ} \mathrm{C}$, and maximal volume is about $150 \mathrm{~cm}^{3}$.

Pressure sensor: It is $0 \sim 100 \mathrm{MPa}$, and precision of pressure control is 1 Psi.

Temperature sensor: it is $-100 \sim 200^{\circ} \mathrm{C}$, and precision of temperature control is $\pm 0.1^{\circ} \mathrm{C}$.

Thermostatic air bath: the highest operation temperature is $200^{\circ} \mathrm{C}$ and precision of temperature control is $\pm 0.1^{\circ} \mathrm{C}$.

Sample container: it is $130 \mathrm{~cm}^{3}$.

Automatic pump: rated operation pressure is $100 \mathrm{MPa}$ with resolution of $1 \mathrm{Psi}$, and the range of operation pump volume is $500 \mathrm{~cm}^{3}$ with resolution of $0.001 \mathrm{~cm}^{3}$.

Electronic balance: it is $0 \sim 500 \mathrm{~g}$, and precision of weight control is $0.001 \mathrm{~g}$.
The accuracy of PVT main parts satisfies the phase behavior experimental requirement of the synthetic gas sample with different $\mathrm{CO}_{2}$ content [31].

3.3. Experimental Procedures. Experimental procedures are as follows:

(1) Clean PVT vessel and cells; then connect the PVT vessel to cells and evacuate the cells.

(2) Prepare the gas samples, and control and maintain the desired temperature using the constant temperature air bath.

(3) Introduce a test gas about $50 \mathrm{~mL}$ (YP9 gas sample) into PVT vessel at the specified temperature and pressure in the oven and keep it for $5 \mathrm{~h}$, and then hold on an hour and measure the gas volume of the PVT vessel.

(4) Two-flash experiment: slightly open the valve between the cells and bleed gas from the PVT vessel into the flash separators, at the same time, and keep the pressure using the automatic pump at formation temperature $\left(127.5^{\circ} \mathrm{C}\right)$.

(5) Record the bled gas volumes using the gasometer and remaining gas volumes of PVT vessel.

(6) The bled gas was analyzed using gas chromatograph.

(7) Constant composition expansion experiment (CCE experiment) or $P-V$ relationship experiment: pressure was reduced step by step from initial formation pressure to the limit pressure of the piston movement under the formation temperature. The volumes were recorded when each pressure was stable.

(8) Step (7) was repeated at $35^{\circ} \mathrm{C}, 75^{\circ} \mathrm{C}$, and $127.5^{\circ} \mathrm{C}$, respectively. $P-V$ relationship experiment was tested at least three times under each temperature and the average value was calculated.

(9) Two-flash experiments and CCE experiments were also performed on the other three gas samples by repeating step (3) to step (8).

(10) The gas sample with the highest content of $\mathrm{CO}_{2}$ (75.323 mol\%) was introduced into the PVT vessel to study whether phase transition in high $\mathrm{CO}_{2}$ content natural gas takes place from formation to well head. The experimental temperatures are $-10^{\circ} \mathrm{C}$ and $35^{\circ} \mathrm{C}$, respectively.

\section{Results and Discussion}

4.1. Two-Flash and CCE Experiments. The results of two-flash experiments are listed in Table 3. Formation volumes (under the formation conditions) and ground volumes (under the standard conditions) are the experimental measurements, and density, molecular weight, formation volume factor, and $Z$-factor are calculated by using gas state equation. The gas state equation is expressed as follows [27].

Under the formation conditions one has

$$
P_{t} V_{t}=n R Z_{t} T_{t}
$$




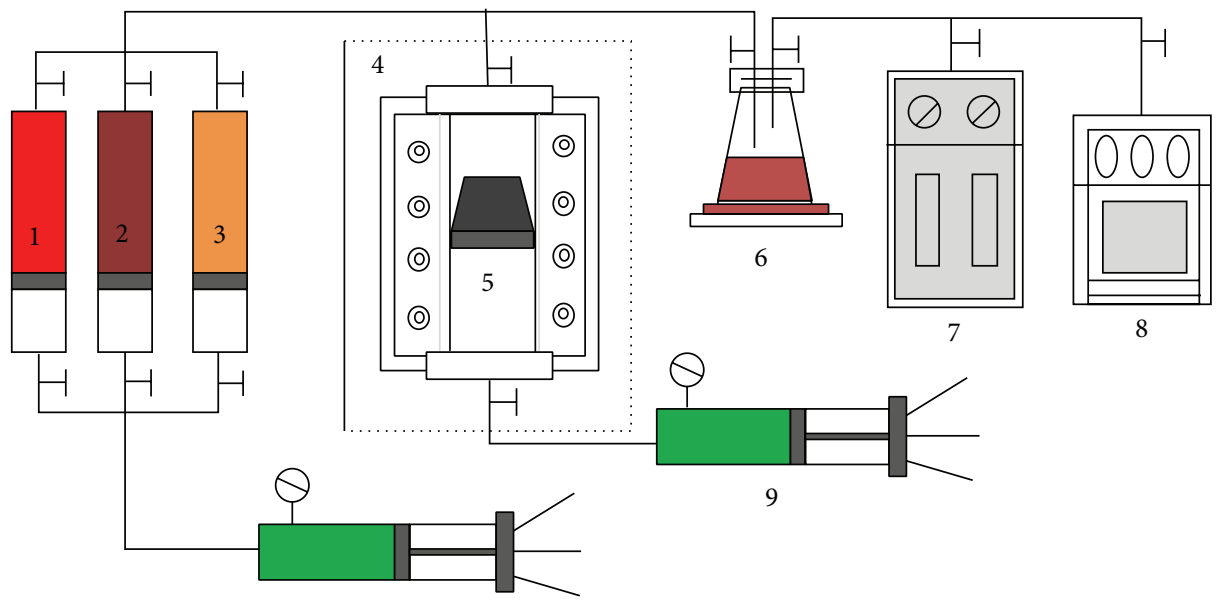
(1) $\mathrm{CO}_{2}$ sample
(2) High $\mathrm{CO}_{2}$ content natural gas
(3) Without or low $\mathrm{CO}_{2}$ content natural gas
(4) Thermostatic system
(5) PVT cell

(6) Flash separator and electronic balance

(7) Gasometer

(8) Gas chromatography

(9) Automatic pump

FIGURE 4: Schematic diagram of the experimental apparatus.

TABLE 3: Results from two-flash experiments for different $\mathrm{CO}_{2}$ contents in natural gas.

\begin{tabular}{lcccc}
\hline Parameters & Gas1 & YP9 & Gas2 & Gas3 \\
\hline Formation volume $/ V_{t}\left(\mathrm{~cm}^{3}\right)$ & 2.97 & 3.951 & 3.762 & 1155 \\
Ground volume $/ V_{\mathrm{sc}}\left(\mathrm{cm}^{3}\right)$ & 850 & 1135 & 0.676 \\
Formation volume factor $/ B_{g t}$ & 0.003496 & 0.003481 & 0.003257 & 0.9885 \\
$Z$-factor $/ Z_{t}$ & 1.0702 & 1.0663 & 398.75 & 0.9295 \\
Gas density $/ \rho_{t}\left(\mathrm{~kg} / \mathrm{m}^{3}\right)$ & 230.00 & 268.51 & 30.55 & 494.13 \\
(under the formation conditions) & 19.85 & 22.49 & 1.0545 & 35.92 \\
Molecular weight $/ M(\mathrm{~g} / \mathrm{mol})$ & 0.6853 & 0.7763 & & 1.2398 \\
Relative density $/ \gamma_{g}$ & & &
\end{tabular}

Under the standard conditions one has

$$
P_{\mathrm{sc}} V_{\mathrm{sc}}=n R Z_{\mathrm{sc}} T_{\mathrm{sc}}
$$

$P_{t}$ is the formation pressure; $V_{t}$ is the gas volume under the formation conditions; $Z_{t}$ is the deviation factor under the formation conditions; $T_{t}$ is the formation temperature; $n$ is the number of moles; $R$ is the gas general constant, 8.3147 $\mathrm{MPa} \cdot \mathrm{cm}^{3} \cdot \mathrm{mol}^{-1} \cdot \mathrm{K}^{-1} ; P_{\mathrm{sc}}$ is the atmospheric pressure, and it is usually approximately equal to $0.101325 \mathrm{MPa} ; V_{\mathrm{sc}}$ is the gas volume under the standard conditions; $Z_{\mathrm{sc}}$ is the deviation factor under the standard conditions, and it is usually approximately equal to $1 ; T_{\mathrm{sc}}$ is the standard temperature, and it is usually approximately equal to $20^{\circ} \mathrm{C}$. [27]:

Relative densities are calculated by using the following

$$
\gamma_{g}=\frac{M}{M_{\text {air }}}
$$

$M$ is the gas molecular weight; $M_{\text {air }}$ is the air molecular weight, and it is usually approximately equal to $28.97 \mathrm{~g} / \mathrm{mol}$.
We can draw the conclusion from Table 3 that the density, molecular weight, and relative density increase with increasing $\mathrm{CO}_{2}$ content in natural gas, while the formation volume factor and $Z$-factor decrease with increasing $\mathrm{CO}_{2}$ content in natural gas.

CCE experiment was performed to draw the relative volume, $Z$-factor, formation volume factor, and density under the grading pressure. And the results are shown from Figures 5-12.

4.1.1. Effect of Temperature. The effect of temperature on the physical properties of YP9 gas sample was, respectively, tested under the formation temperature $\left(127.5^{\circ} \mathrm{C}\right)$, the temperature in the well $\left(75^{\circ} \mathrm{C}\right)$, and the ground temperature $\left(35^{\circ} \mathrm{C}\right)$. It can be seen from Figures 5-7 that the relative volume and formation volume factor of high $\mathrm{CO}_{2}$ content natural gases increase with increasing temperature under constant pressure, while the density of gas decreases with increasing temperature under constant pressure. And the relative volume and formation volume factor of high $\mathrm{CO}_{2}$ content natural gases decrease with increasing pressure at isothermal 


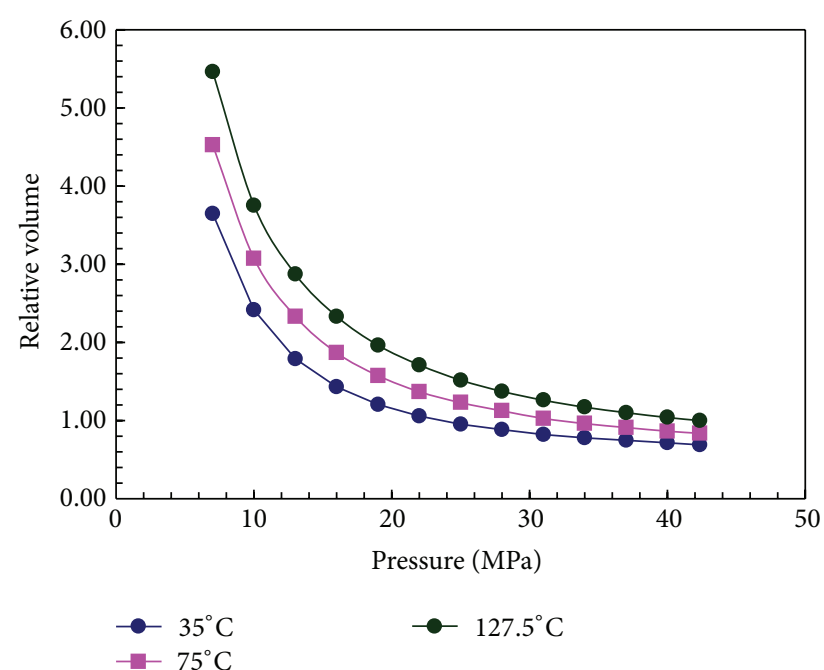

FIGURE 5: Variation of the relative volume of YP9 gas sample with pressure under different temperatures.

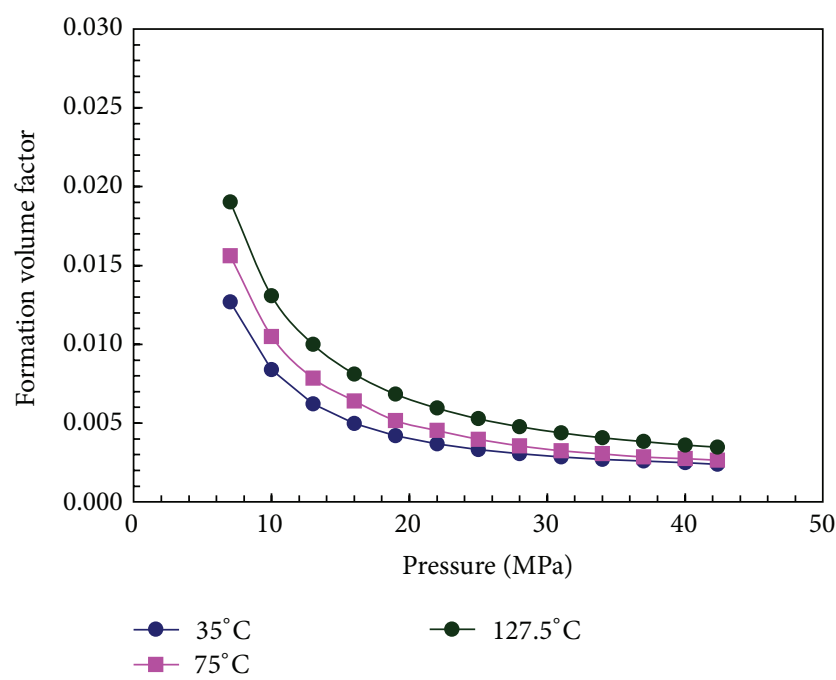

FIGURE 6: Variation of the formation volume factor of YP9 gas sample with pressure under different temperatures.

conditions. The effects of temperature and pressure on the experimental $Z$-factors for YP9 gas sample are shown in Figure 8 . It can be seen clearly form Figure 8 that $Z$-factor decreases with increasing pressure at lower pressure range, that is, less than $18 \mathrm{MPa}$, while it increases with increasing pressure at higher pressures, that is, higher than $18 \mathrm{MPa}$. And the $Z$-factor decreases with decreasing temperature and a greater decrease can be observed in a pressure range from about $15 \mathrm{MPa}$ to $22 \mathrm{MPa}$ [32].

4.1.2. Effect of $\mathrm{CO}_{2}$ Content. Experimental relative volumes, formation volume factors, and densities of different $\mathrm{CO}_{2}$ content natural gases are shown from Figures 9-11. It can be seen clearly from Figures 9-11 that relative volume and formation volume factor decrease with increasing $\mathrm{CO}_{2}$ content

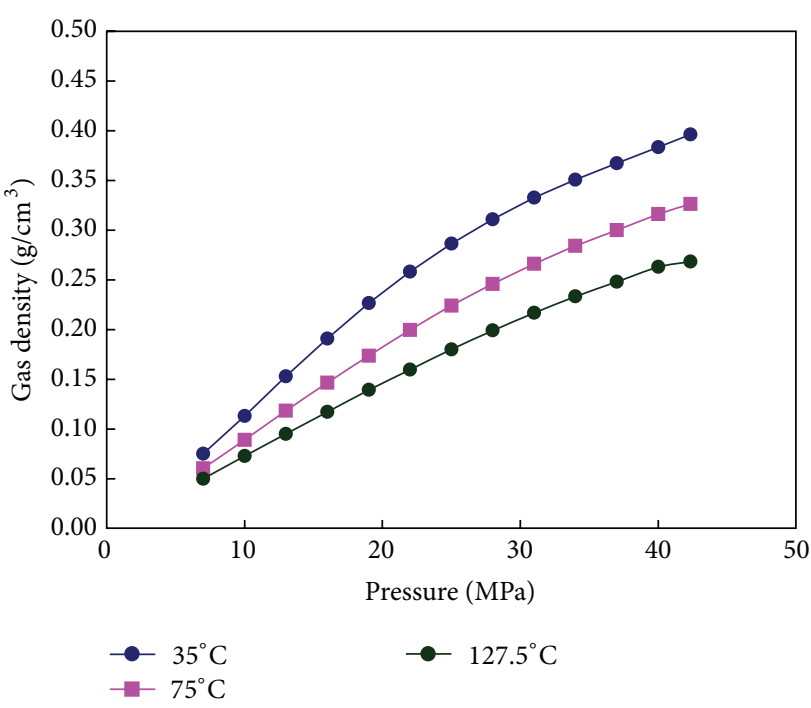

FIGURE 7: Variation of the gas density of YP9 gas sample with pressure under different temperatures.

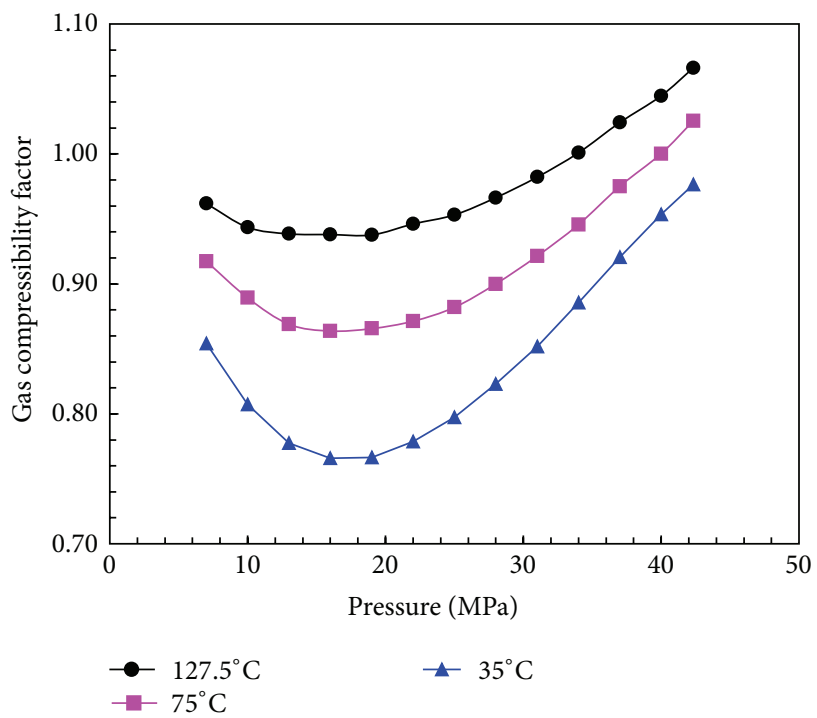

FIGURE 8: Variation of the Z-factor of YP9 gas sample with pressure under different temperatures.

in natural gas at $127.5^{\circ} \mathrm{C}$ isothermal and constant pressure conditions, but they do not change insignificantly. The effects of $\mathrm{CO}_{2}$ content in natural gas on the experimental $Z$-factors of different $\mathrm{CO}_{2}$ content natural gases are shown in Figure 12. It can be seen from Figure 12 that $Z$-factor decreases with increasing $\mathrm{CO}_{2}$ content in natural gas at $127.5^{\circ} \mathrm{C}$ isothermal and constant pressure conditions. And the dependence of the pressure follows the same trends as mentioned in Figure 5.

4.2. Effect of $\mathrm{CO}_{2}$ Content on P-T Diagram. In order to test and draw the $P-T$ phase diagram of the high $\mathrm{CO}_{2}$ content natural gas, we have tested saturation pressures of the high $\mathrm{CO}_{2}$ content natural gases at different temperatures $\left(-60^{\circ} \mathrm{C},-50^{\circ} \mathrm{C},-40^{\circ} \mathrm{C},-30^{\circ} \mathrm{C},-20^{\circ} \mathrm{C},-10^{\circ} \mathrm{C}\right.$, and $\left.0^{\circ} \mathrm{C}\right)$ based 
TABLE 4: Saturation pressure calculated by using the model proposed in this paper and experimental measured saturation pressure.

\begin{tabular}{lcccccccc}
\hline & \multicolumn{3}{c}{ Gas1 } & \multicolumn{3}{c}{ YP9 } & \multicolumn{3}{c}{ Gas2 } & \multicolumn{3}{c}{ Gas3 } \\
Parameters & $\begin{array}{c}\text { Calculated } \\
\text { value } \\
(\mathrm{MPa})\end{array}$ & $\begin{array}{c}\text { Measured } \\
\text { value } \\
(\mathrm{MPa})\end{array}$ & $\begin{array}{c}\text { Calculated } \\
\text { value } \\
(\mathrm{MPa})\end{array}$ & $\begin{array}{c}\text { Measured } \\
\text { value } \\
(\mathrm{MPa})\end{array}$ & $\begin{array}{c}\text { Calculated } \\
\text { value } \\
(\mathrm{MPa})\end{array}$ & $\begin{array}{c}\text { Measured } \\
\text { value } \\
(\mathrm{MPa})\end{array}$ & $\begin{array}{c}\text { Calculated } \\
\text { value } \\
(\mathrm{MPa})\end{array}$ & $\begin{array}{c}\text { Measured } \\
\text { value } \\
(\mathrm{MPa})\end{array}$ \\
\hline Saturation pressure $\left(-60^{\circ} \mathrm{C}\right)$ & 6.21 & 6.05 & 6.28 & 6.11 & 4.88 & 4.62 & $/$ & $/$ \\
Saturation pressure $\left(-50^{\circ} \mathrm{C}\right)$ & 6.75 & 6.68 & 7.05 & 6.92 & 5.69 & 5.51 & 3.99 & 3.75 \\
Saturation pressure $\left(-40^{\circ} \mathrm{C}\right)$ & 6.08 & 6.01 & 6.88 & 6.98 & 6.48 & 6.66 & 4.68 & 4.45 \\
Saturation pressure $\left(-30^{\circ} \mathrm{C}\right)$ & $/$ & $/$ & $/$ & $/$ & 7.32 & 7.15 & 5.42 & 5.65 \\
Saturation pressure $\left(-20^{\circ} \mathrm{C}\right)$ & $/$ & $/$ & $/$ & $/$ & 8.13 & 8.45 & 6.23 & 6.35 \\
Saturation pressure $\left(-10^{\circ} \mathrm{C}\right)$ & $/$ & $/$ & $/$ & $/$ & 8.48 & 8.65 & 7.08 & 6.95 \\
Saturation pressure $\left(0^{\circ} \mathrm{C}\right)$ & $/$ & $/$ & $/$ & $/$ & $/$ & $/$ & 7.85 & 8.02 \\
\hline
\end{tabular}

Note: " $l$ " shows that no saturation pressure is measured and calculated.

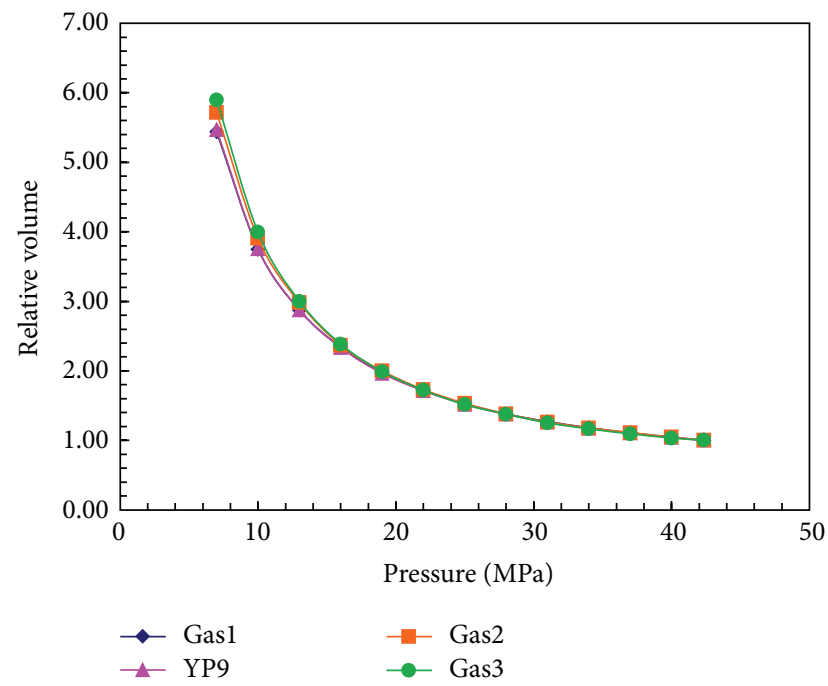

FIGURE 9: Variation of the relative volume of different $\mathrm{CO}_{2}$ content natural gas samples with pressure at $127.5^{\circ} \mathrm{C}$.

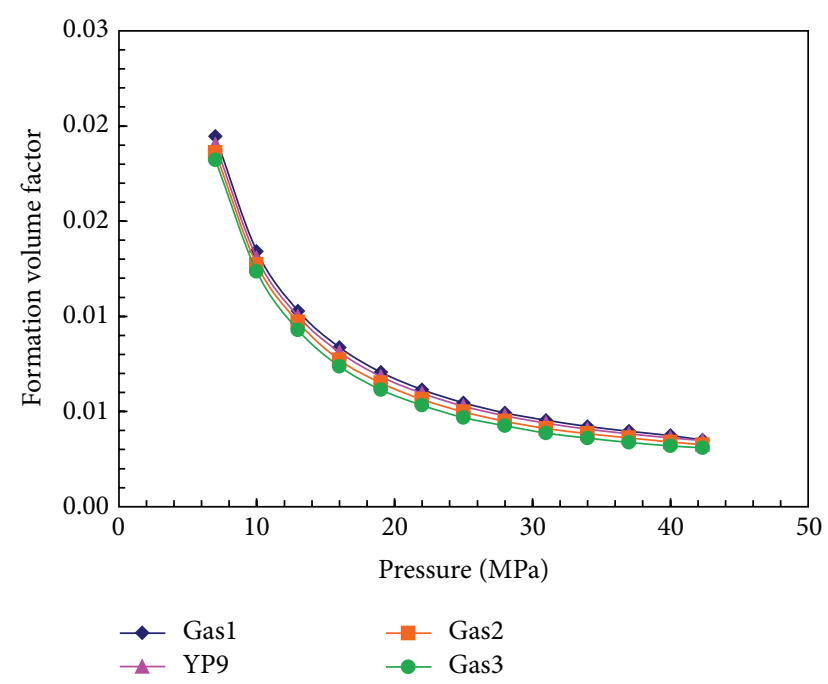

Figure 10: Variation of the volume factor of different $\mathrm{CO}_{2}$ content natural gas samples with pressure at $127.5^{\circ} \mathrm{C}$.

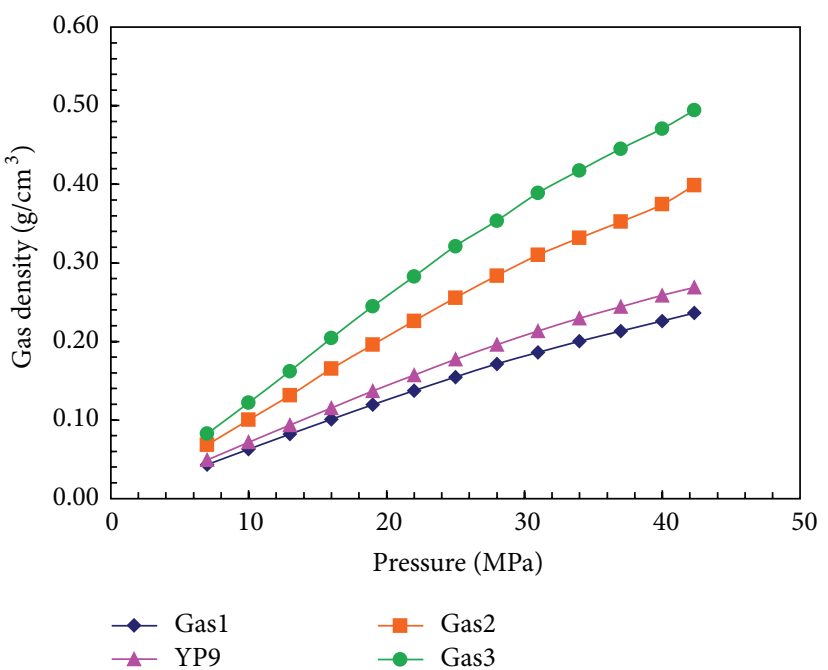

FIGURE 11: Variation of the gas density of different $\mathrm{CO}_{2}$ content natural gas samples with pressure at $127.5^{\circ} \mathrm{C}$.

on the above CCE experimental test methods. The test results are shown in Table 4 . At the same time, saturation pressures at the corresponding conditions are calculated by using (1) to (7), and the tested saturation pressures are fitted by adjusting critical parameters (critical temperature and critical pressure) of $\mathrm{C}_{6}$ on the basis of the fixed binary interaction coefficients in the process of calculation; the calculated results are also shown in Table $4 . \mathrm{C}_{6}$ has several isomers; the critical parameters are not fixed, so we choose the critical parameters of $\mathrm{C}_{6}$ as adjustable parameters to fit the saturation pressure of different $\mathrm{CO}_{2}$ content natural gases. The fixed binary interaction coefficients are given in Table 6 and the critical parameters (critical temperatures and critical pressures) of $\mathrm{C}_{6}$ are given in Table 7 . It can be seen from Table 7 that the higher the $\mathrm{CO}_{2}$ content, the higher the critical temperature, the lower the critical pressure, and the heavier the system (different $\mathrm{CO}_{2}$ content natural gas). And we compare the saturation pressure calculated by using the model proposed in this paper with the experimental measured saturation pressure; the deviations between the 


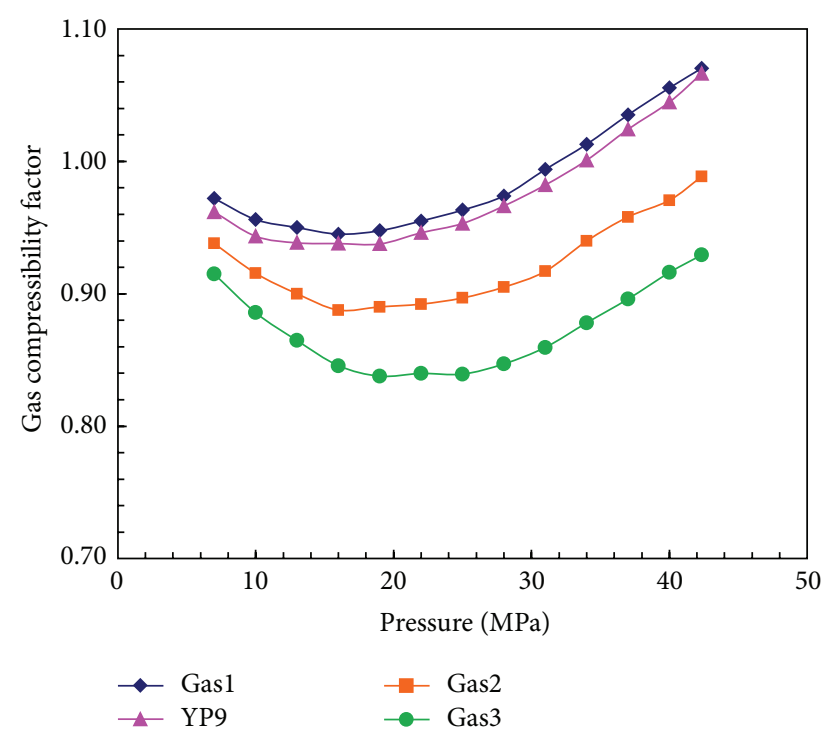

FIGURE 12: Variation of the $Z$-factor of different $\mathrm{CO}_{2}$ content natural gas samples with pressure at $127.5^{\circ} \mathrm{C}$.

saturation pressure calculated by using the model proposed in this paper and experimental measured saturation pressure are shown in Table 5. The absolute relative error (11) and the average absolute relative error (12) are used to express the deviation between the saturation pressure calculated by using the model proposed in this paper and the experimental measured saturation pressure. We can draw the conclusion from Table 5 that the temperatures are colder, the absolute relative error is greater, and the higher the $\mathrm{CO}_{2}$ content in natural gas, the greater the absolute relative error. The average relative errors of Gas1, YP9, Gas2, and Gas 3 are 1.62\%, $2.03 \%, 3.29 \%$, and $3.38 \%$, respectively. Overall, the deviations between the saturation pressure calculated by using the model proposed in this paper and experimental measured saturation pressure are very small; the average relative error of all the gas samples is $2.86 \%$. So it shows that the model can be used to predict the $P-T$ phase diagram of the high $\mathrm{CO}_{2}$ content natural gas. Consider

$$
\begin{gathered}
\operatorname{ARE}(\%)=\sum_{i=1}^{N}\left|\frac{\mathrm{Cal}-\operatorname{Exp}}{\operatorname{Exp}}\right|_{i} \times 100, \\
\operatorname{AARE}(\%)=\frac{1}{N} \sum_{i=1}^{N}\left|\frac{\mathrm{Cal}-\operatorname{Exp}}{\operatorname{Exp}}\right|_{i} \times 100 .
\end{gathered}
$$

$P-T$ diagrams and critical points of different $\mathrm{CO}_{2}$ content natural gases in the gas-liquid two-phase region were drawn using (1) to (7); the calculated results are shown in Figures 13 and 14. And $P-T$ diagrams and critical points of pure methane and pure $\mathrm{CO}_{2}$ in Figures 13 and 14 refer to the experimental data from the literature [33, 34]. In Figure 13, the vapor-liquid critical locus exits in the pure $\mathrm{CH}_{4}$ critical point extending continuously toward the $\mathrm{CO}_{2}$ critical point [35]. Three-phase loci originating from triple-point of pure $\mathrm{CO}_{2}$ ends in the triple-point of $\mathrm{CH}_{4}$ [35]. Here, we only consider the gas-liquid two-phase region, because it is found

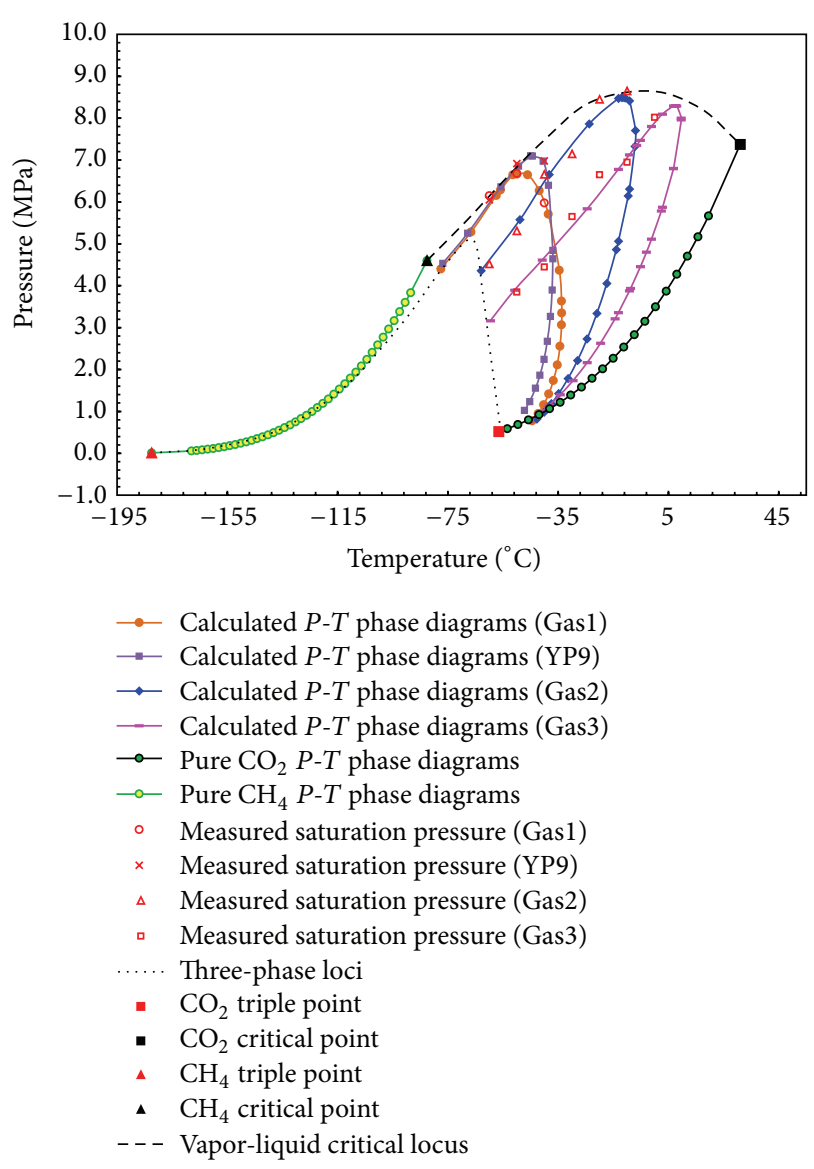

FIGURE 13: Calculated $P-T$ phase diagrams and measured saturation pressure of natural gas with different $\mathrm{CO}_{2}$ contents.

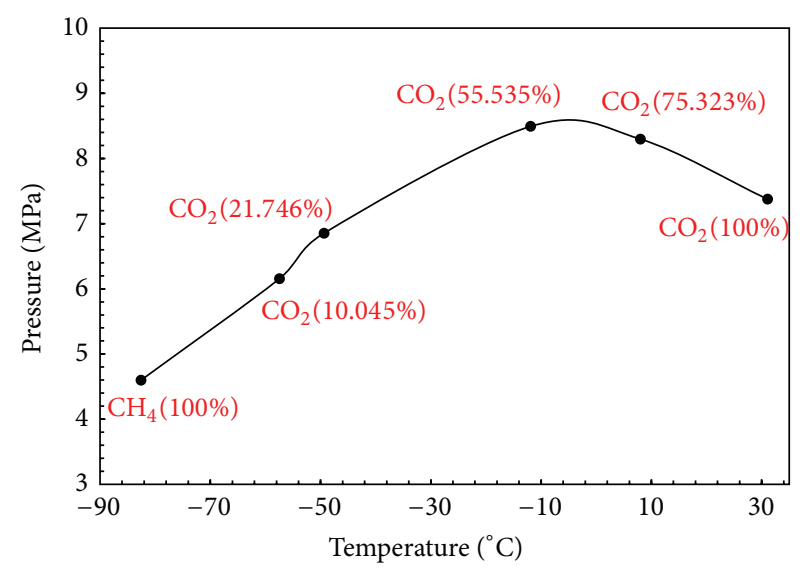

FIGURE 14: Variation curve of the critical points of natural gas with different $\mathrm{CO}_{2}$ contents.

in the process of calculation that the model proposed in this study is only applied to calculate the gas-liquid phase equilibrium, while it is not applied to calculate the gassolid, liquid-solid, and gas-liquid-solid phase equilibrium. We can draw the conclusion from Figures 13 and 14 that as $\mathrm{CO}_{2}$ content in natural gas increases, the two-phase envelope 
TABLE 5: The deviations between the saturation pressure calculated by using the model proposed in this paper and experimental measured saturation pressure.

\begin{tabular}{|c|c|c|c|c|c|c|c|c|c|}
\hline Parameters & $\begin{array}{c}\text { Gas1 } \\
\text { ARE, \% }\end{array}$ & $\begin{array}{c}\text { Gas1 } \\
\text { AARE, \% }\end{array}$ & $\begin{array}{c}\text { YP9 } \\
\text { ARE, \% }\end{array}$ & $\begin{array}{c}\text { YP9 } \\
\text { AARE, \% }\end{array}$ & $\begin{array}{c}\text { Gas2 } \\
\text { ARE/\% }\end{array}$ & $\begin{array}{c}\text { Gas2 } \\
\text { AARE/\% }\end{array}$ & $\begin{array}{c}\text { Gas3 } \\
\text { ARE/\% }\end{array}$ & $\begin{array}{c}\text { Gas3 } \\
\text { AARE/\% }\end{array}$ & $\begin{array}{c}\text { Total } \\
\text { AARE/\% }\end{array}$ \\
\hline Saturation pressure $\left(-60^{\circ} \mathrm{C}\right)$ & 2.64 & & 2.78 & & 5.63 & & I & & \\
\hline Saturation pressure $\left(-50^{\circ} \mathrm{C}\right)$ & 1.05 & & 1.88 & & 3.27 & & 6.40 & & \\
\hline Saturation pressure $\left(-40^{\circ} \mathrm{C}\right)$ & 1.16 & & 1.43 & & 2.70 & & 5.17 & & \\
\hline Saturation pressure $\left(-30^{\circ} \mathrm{C}\right)$ & l & 1.62 & l & 2.03 & 2.38 & 3.29 & 4.07 & 3.38 & 2.86 \\
\hline Saturation pressure $\left(-20^{\circ} \mathrm{C}\right)$ & I & & l & & 3.79 & & 1.89 & & \\
\hline Saturation pressure $\left(-10^{\circ} \mathrm{C}\right)$ & l & & l & & 1.97 & & 1.87 & & \\
\hline Saturation pressure $\left(0^{\circ} \mathrm{C}\right)$ & l & & l & & l & & 2.12 & & \\
\hline
\end{tabular}

TABLE 6: Binary interaction parameters $\left(k_{i j}\right)$ and mixing rules for the model proposed in this study.

\begin{tabular}{lcccccccccc}
\hline Components & $\mathrm{CO}_{2}$ & $\mathrm{~N}_{2}$ & $\mathrm{C}_{1}$ & $\mathrm{C}_{2}$ & $\mathrm{C}_{3}$ & $i \mathrm{C}_{4}$ & $n \mathrm{C}_{4}$ & $i \mathrm{C}_{5}$ & $n \mathrm{C}_{5}$ & $\mathrm{C}_{6}$ \\
\hline $\mathrm{CO}_{2}$ & 0 & -0.02 & 0.103 & 0.130 & 0.135 & 0.130 & 0.130 & 0.125 & 0.125 & 0.150 \\
$\mathrm{~N}_{2}$ & -0.02 & 0 & 0.031 & 0.042 & 0.091 & 0.095 & 0.095 & 0.095 & 0.095 & 0.120 \\
$\mathrm{C}_{1}$ & 0.103 & 0.031 & 0 & 0.003 & 0.009 & 0.016 & 0.015 & 0.021 & 0.021 & 0.025 \\
$\mathrm{C}_{2}$ & 0.13 & 0.042 & 0.003 & 0 & 0.002 & 0.005 & 0.005 & 0.009 & 0.009 & 0.012 \\
$\mathrm{C}_{3}$ & 0.135 & 0.091 & 0.009 & 0.002 & 0 & 0.001 & 0.001 & 0.003 & 0.003 & 0.005 \\
$i \mathrm{C}_{4}$ & 0.13 & 0.095 & 0.016 & 0.005 & 0.001 & 0 & 0.000 & 0.000 & 0.000 & 0.001 \\
$n \mathrm{C}_{4}$ & 0.13 & 0.095 & 0.015 & 0.005 & 0.001 & 0.000 & 0 & 0.001 & 0.001 & 0.001 \\
$i \mathrm{C}_{5}$ & 0.125 & 0.095 & 0.021 & 0.009 & 0.003 & 0.000 & 0.001 & 0 & 0.000 & 0.000 \\
$n \mathrm{C}_{5}$ & 0.125 & 0.095 & 0.021 & 0.009 & 0.003 & 0.000 & 0.001 & 0.000 & 0 & 0.000 \\
$\mathrm{C}_{6}$ & 0.15 & 0.12 & 0.025 & 0.012 & 0.005 & 0.001 & 0.001 & 0.000 & 0.000 & zero \\
\hline
\end{tabular}

TABLE 7: The critical parameters (critical temperature and critical pressure) of $\mathrm{C}_{6}$.

\begin{tabular}{lcc}
\hline Sample & Critical temperature, ${ }^{\circ} \mathrm{C}$ & Critical pressure, $\mathrm{MPa}$ \\
\hline Gas1 & 235.95 & 2.934 \\
YP9 & 242.45 & 2.889 \\
Gas2 & 255.65 & 2.776 \\
Gas3 & 268.95 & 2.740 \\
\hline
\end{tabular}

moves right and two-phase region becomes narrower. And critical point of natural gas moves to upper right (reaching a maximum), and finally it moves to lower right. The maximum critical pressure is $8.49 \mathrm{MPa}$ when $\mathrm{CO}_{2}$ is about $55.535 \mathrm{~mol} \%$. The closer the distribution ratio of $\mathrm{CH}_{4}$ and $\mathrm{CO}_{2}$, the larger the two-phase region. Furthermore, comparing the contents of $\mathrm{CH}_{4}$ and $\mathrm{CO}_{2}$, as one component becomes more predominant, the $P-T$ diagram tends to approach the vapor pressure curve ( $P-T$ diagram of one component) of the major component. The critical pressure of natural gas with high $\mathrm{CO}_{2}$ content increases with increasing $\mathrm{CO}_{2}$ content in natural gas when $\mathrm{CO}_{2}$ content in natural gas is below $55.535 \mathrm{~mol} \%$, while the critical pressure of high $\mathrm{CO}_{2}$ content natural gas decreases with increasing $\mathrm{CO}_{2}$ content in natural gas when $\mathrm{CO}_{2}$ content in natural gas is above $55.523 \mathrm{~mol} \%$. But the critical temperature constantly increases with increasing $\mathrm{CO}_{2}$ content in natural gas.

4.3. Phase Transition Observation Experiment. It can be seen from Section 4.2 that the critical temperature increases with increasing $\mathrm{CO}_{2}$ content in natural gas. And in order to facilitate reducing the temperature, we chose the gas sample with $\mathrm{CO}_{2}$ content of $75.323 \mathrm{~mol} \%$ as the research object. The result of phase transition observation experiment is shown in Figures 15 and 16. We can draw the conclusion that phase transition of gas sample with $\mathrm{CO}_{2}$ content of $75.323 \mathrm{~mol} \%$ does not take place as pressure decreases from $42.34 \mathrm{MPa}$ to $5 \mathrm{MPa}$ at $35^{\circ} \mathrm{C}$ isothermal conditions, while phase transition of gas sample with $\mathrm{CO}_{2}$ content of $75.323 \mathrm{~mol} \%$ takes place as pressure decreases from $42.34 \mathrm{MPa}$ to $5 \mathrm{MPa}$ at $-10^{\circ} \mathrm{C}$ isothermal conditions. The phase transition process is shown in the red dotted line part in Figure 16. The state of natural gas changes from the original transparent state into the mist. The testing results of phase transition observation experiment consist with the calculation results and testing results in Section 4.2 and, for the four gas samples, no phase transitions will take place at temperatures greater than $35^{\circ} \mathrm{C}$. It also suggests that phase transition does not also take place at $75^{\circ} \mathrm{C}$ isothermal conditions and at $125^{\circ} \mathrm{C}$ isothermal conditions. It is illustrated that in the four gas samples no gas-liquid phase transition happens from bottom hole to well head.

\section{Conclusions}

Conclusions are as follows:

(1) For the four high $\mathrm{CO}_{2}$ content gas samples, no phase transitions will take place at temperatures greater than $35^{\circ} \mathrm{C}$. It is illustrated that in the four gas samples no 


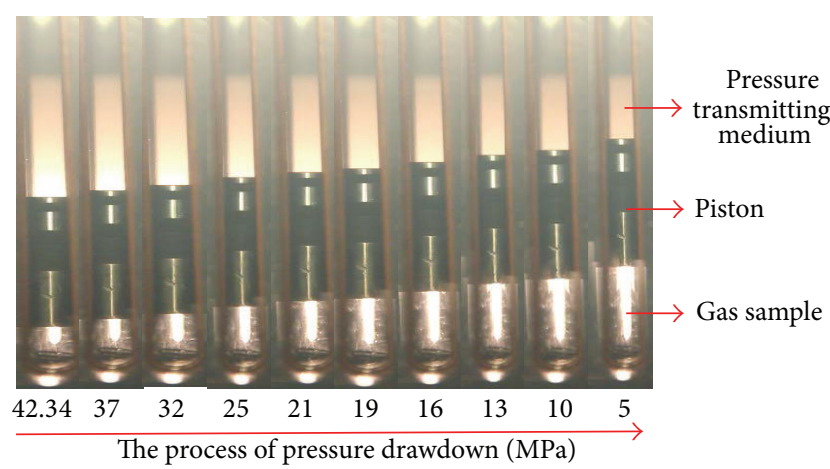

FIGURE 15: Phase transition of high $\mathrm{CO}_{2}$ content natural gas samples $(75.323 \mathrm{~mol} \%)$ in the process of pressure drawdown at $35^{\circ} \mathrm{C}$.

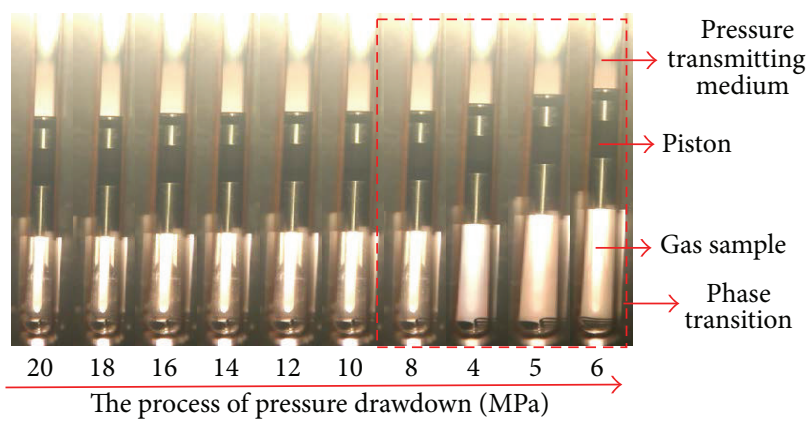

Figure 16: Phase transition of high $\mathrm{CO}_{2}$ content natural gas sample $(75.323 \mathrm{~mol} \%)$ in the process of pressure drawdown at $-10^{\circ} \mathrm{C}$.

gas-liquid phase transition happens from bottom hole to well head.

(2) Relative volume and formation volume factor of four gas samples in this paper decrease with increasing pressure at isothermal conditions, while densities of four gas samples increase with increasing pressure at isothermal conditions. At isothermal conditions $Z$ factors of four gas samples decrease with increasing pressure at lower pressure range, that is, less than $18 \mathrm{MPa}$, while they increase with increasing pressure at higher pressure range, that is, higher than $18 \mathrm{MPa}$.

(3) Relative volumes, formation volume factors, and $Z$ factors of four gas samples increase with increasing temperature at constant pressure conditions, while densities of four gas samples decrease with increasing temperature at constant pressure.

(4) Formation volume factors and $Z$-factors of four gas samples decrease with increasing $\mathrm{CO}_{2}$ content in natural gas at isothermal and constant pressure conditions, but relative volumes and volume factors do not change insignificantly. And densities of four gas samples increase with increasing $\mathrm{CO}_{2}$ content in natural gas at isothermal and constant pressure conditions.

(5) The deviations between the saturation pressure calculated by using the model proposed in this paper and experimental measured saturation pressure are very small; the average relative error is only $2.86 \%$. Thus, the model can be used to predict the saturation pressure of high $\mathrm{CO}_{2}$ content natural gas.

(6) In the gas-liquid two-phase region, as $\mathrm{CO}_{2}$ content in natural gas increases, the two-phase envelope moves right and two-phase region becomes narrower. And critical point of natural gas proposed in this paper moves to upper right (reaching a maximum) and then moves to lower right. The maximum critical pressure is $8.49 \mathrm{MPa}$ when $\mathrm{CO}_{2}$ content is about $55.535 \mathrm{~mol} \%$.

\section{Conflict of Interests}

Here, all the authors solemnly declare that there is no conflict of interests regarding the publication of this paper.

\section{Acknowledgments}

The authors wish to acknowledge anonymous reviewers for constructive comments and suggestions for improving this paper. The authors also wish to thank the anonymous Associate Editor for his handling of the paper and additional suggestions. This work was supported by National Science and Technology Major Project of China (no. 2011ZX05016005-2) and a grant from the National Natural Science Foundation of China (no. 50604011).

\section{References}

[1] Y. Hu, J. F. Du, P. Guo et al., "Experimental study on Z-factor of high $\mathrm{CO}_{2}$ content natural gas," Journal of Southern Yangtze University (Natural Science), vol. 6, no. 2, pp. 192-194, 2009.

[2] H. Anping, D. Jinxing, Y. Chun, Z. Qinghua, and N. Yunyan, "Geochemical characteristics and distribution of $\mathrm{CO}_{2}$ gas fields in Bohai Bay Basin," Petroleum Exploration and Development, vol. 36, no. 2, pp. 181-189, 2009.

[3] T. J. Hughes, M. E. Kandil, B. F. Graham, and E. F. May, "Simulating the capture of $\mathrm{CO}_{2}$ from natural gas: new data and improved models for methane + carbon dioxide + methanol," International Journal of Greenhouse Gas Control, vol. 31, pp. 121127, 2014.

[4] H. Sriyanta, M. A. Malek, M. A. Zulhairi et al., "Operational challenges in managing high $\mathrm{CO}_{2}$ content gas production in Peninsular Malaysia operations," in Proceedings of the International Petroleum Technology Conference, SPE 17082, Beijing, China, March 2013.

[5] S. I. Putu and P. T. Pertamina, "Producing high $\mathrm{CO}_{2}$ gas content reservoirs in Pertamina Indonesia using multi stage cryogenic process," in Proceedings of the SPE Asia Pacific Oil and Gas Conference and Exhibition, SPE 134278, Brisbane, Australia, October 2010.

[6] S. L. Li and Y. Hua, Condensate Gas Exploration and Development Technology, Sichuan Science and Technology Press, Chengdu, China, 2000.

[7] X. Q. Bian, Z. M. Du, and Y. Tang, "Experimental determination and prediction of the compressibility factor of high $\mathrm{CO}_{2}$ content natural gas with and without water vapor," Journal of Natural Gas Chemistry, vol. 20, no. 4, pp. 364-371, 2011. 
[8] Y. Su, Y. Tang, Y. Xiao, H. Song, and X. Zhang, "Impacts of $\mathrm{CO}_{2}$ content on the development indexes of volcanic gas reservoirs," Natural Gas Industry, vol. 31, no. 8, pp. 69-72, 2011.

[9] X. Q. Bian and Z. M. Du, "Experimental study on the phase behavior and fluid physical parameters of high $\mathrm{CO}_{2}$-content natural gas," Xinjiang Petroleum Geology, vol. 34, no. 1, pp. 6365, 2013.

[10] X. Bian, Z. Du, and Y. Tang, "Experimental determination and prediction of the compressibility factor of high $\mathrm{CO}_{2}$ content natural gas with and without water vapor," Journal of Natural Gas Chemistry, vol. 20, no. 4, pp. 364-371, 2011.

[11] A. Jarrahian and E. Heidaryan, "A new cubic equation of state for sweet and sour natural gases even when composition is unknown," Fuel, vol. 134, pp. 333-342, 2014.

[12] M. Gazzani, E. Macchi, and G. Manzolini, " $\mathrm{CO}_{2}$ capture in natural gas combined cycle with SEWGS. Part A. Thermodynamic performances," International Journal of Greenhouse Gas Control, vol. 12, pp. 493-501, 2013.

[13] C. W. Park, S. Y. Won, C. G. Kim, and Y. Choi, "Effect of mixing $\mathrm{CO}_{2}$ with natural gas-hydrogen blends on combustion in heavy-duty spark ignition engine," Fuel, vol. 102, no. 12, pp. 299-304, 2012.

[14] T. H. Wong, M. Rahim, P. J. Anthony et al., "Challenges in determination of water content and condensed water in a multistacked sour gas field containing high $\mathrm{CO}_{2}$ content offshore Malaysia," in Proceedings of the International Petroleum Technology Conference, SPE 14413, Bangkok, Thailand, November 2011.

[15] C. Q. Li, G. Q. Xue, M. Li et al., "Application of gas well production decline prediction methods to $\mathrm{CO}_{2}$ gas reservoir," Xinjiang Petroleum Geology, vol. 29, no. 5, pp. 613-615, 2008.

[16] B. D. Al-Anazi, G. R. Pazuki, M. Nikookar, and A. F. Al-Anazi, "The prediction of the compressibility factor of sour and natural gas by an artificial neural network system," Petroleum Science and Technology, vol. 29, no. 4, pp. 325-336, 2011.

[17] J. A. Rushing, K. E. Newsham, K. C. van Fraassen et al., "Natural gas $\mathrm{z}$-factors at $\mathrm{HP} / \mathrm{HT}$ reservoir conditions: comparing laboratory measurements with industry-standard correlations for a dry gas," in Proceedings of the CIPC/SPE Gas Technology Symposium Joint Conference, SPE 114518, Calgary, Canada, June 2008.

[18] E. Heidaryan, J. Moghadasi, and M. Rahimi, "New correlations to predict natural gas viscosity and compressibility factor," Journal of Petroleum Science and Engineering, vol. 73, no. 1-2, pp. 67-72, 2010.

[19] F. Tabasinejad, R. G. Moore, S. A. Mehta, Y. Barzin, J. A. Rushing, and K. Edward, "Density of high pressure and temperature gas reservoirs: effect of non-hydrocarbon contaminants on density of natural gas mixtures," in Proceedings of the SPE Western Regional Meeting, SPE 133595, Anaheim, Calif, USA, May 2010.

[20] D.-Y. Peng and D. B. Robinson, "A new two-constant equation of state," Industrial \& Engineering Chemistry Fundamentals, vol. 15, no. 1, pp. 59-64, 1976.

[21] W. A. Fouad and A. S. Berrouk, "Phase behavior of sour natural gas systems using classical and statistical thermodynamic equations of states," Fluid Phase Equilibria, vol. 356, pp. 136-145, 2013.

[22] M. Spiegel, S. Lipschutz, and J. Liu, Schaum's Outline of Mathematical Handbook of Formulas and Tables, McGraw-Hill, New York, NY, USA, 3rd edition, 2008.

[23] H. Saffari and A. Zahedi, "A new alpha-function for the PengRobinson equation of state: application to natural gas," Chinese
Journal of Chemical Engineering, vol. 21, no. 10, pp. 1155-1161, 2013.

[24] B. E. Poling, J. M. Prausnitz, and J. P. O'Connell, The Properties of Gases and Liquids, McGraw-Hill, New York, NY, USA, 2001.

[25] C. L. Yaws, Chemical Properties Handbook, McGraw-Hill, New York, NY, USA, 1999.

[26] B. D. Smith and R. Srivastava, Thermodynamic Data for Pure Compounds, Part A: Hydrocarbons and Ketones, Elsevier, Amsterdam, The Netherlands, 1986.

[27] China National Oil and Gas Industry Standards, SY/T 64342000. Analysis for Natural Gas Reservoir Fluids Physical Properties, China National Oil and Gas Industry Standards, 2000.

[28] R. C. Reid, J. M. Prausnitz, and B. E. Poling, The Properties of Gases and Liquids, McGraw-Hill, New York, NY, USA, 4th edition, 1987.

[29] U. Setzmann and W. Wagner, "A new equation of state and tables of thermodynamic properties for methane covering the range from the melting line to $625 \mathrm{~K}$ at pressures up to $100 \mathrm{MPa}$," Journal of Physical and Chemical Reference Data, vol. 20, no. 6, p. 1061, 1991.

[30] C. R. Zhang and S. Y. Yu, The Test and Evaluation Methods of Carbon Dioxide Gas Well, Petroleum Industry Press, Beijing, China, 1999.

[31] P. Shen, K. Luo, X. Zheng et al., "Experimental study of nearcritical behavior of rich gas condensate systems," in Proceedings of the SPE Production and Operations Symposium, SPE 67285, Oklahoma City, Okla, USA, March 2001.

[32] Z. J. Lu, H. Tang, C. Q. Li et al., "Material balance equation for $\mathrm{CO}_{2}$ gas reservoir considering phase state change," Xinjiang Petroleum Geology, vol. 31, no. 6, pp. 617-620, 2010.

[33] L. N. He, Carbon Dioxide Chemistry, Science Press, Beijing, China, 2013.

[34] S. L. Li, Q. Z. Zhang, X. Q. Ran et al., Enhanced Oil Recovery Technology by Gas Injection, Sichuan Science and Technology Press, Chengdu, China, 2001.

[35] M. Riva, M. Campestrini, J. Toubassy, D. Clodic, and P. Stringari, "Solid-liquid-vapor equilibrium models for cryogenic biogas upgrading," Industrial \& Engineering Chemistry Research, vol. 53, no. 44, pp. 17506-17514, 2014. 

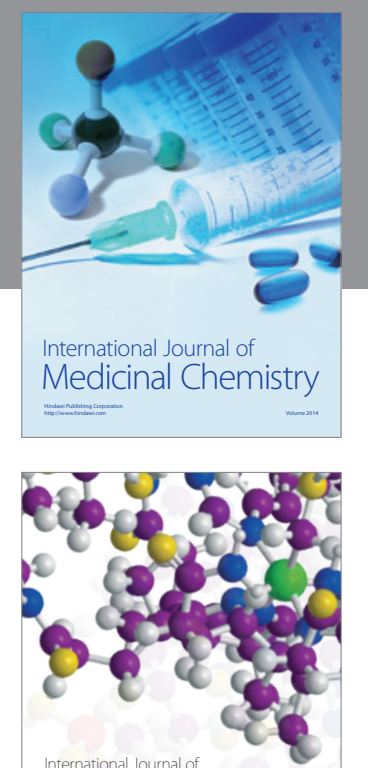

\section{Carbohydrate} Chemistry

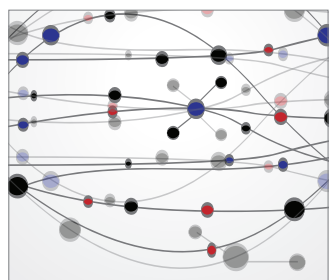

The Scientific World Journal
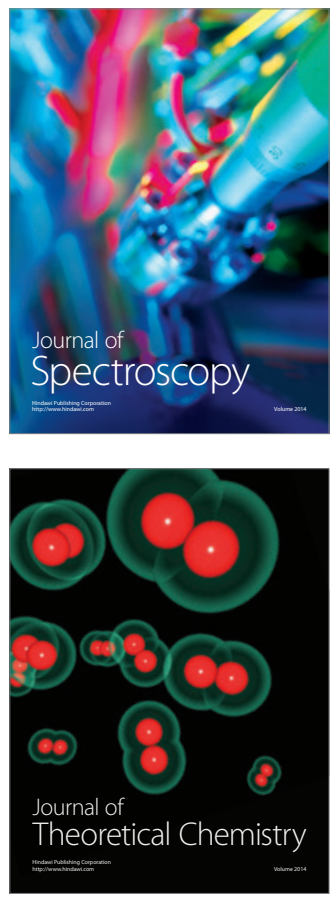
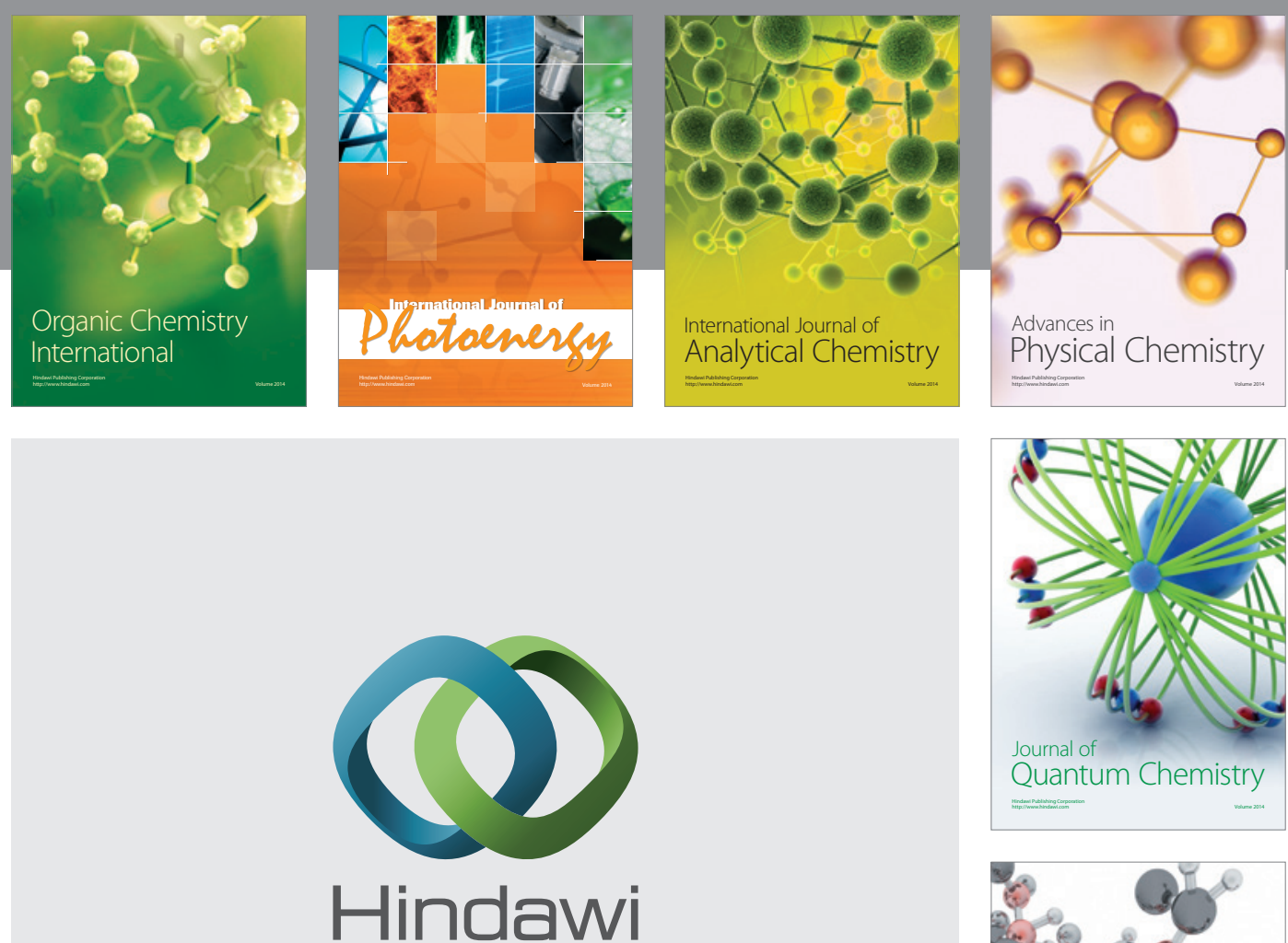

Submit your manuscripts at

http://www.hindawi.com

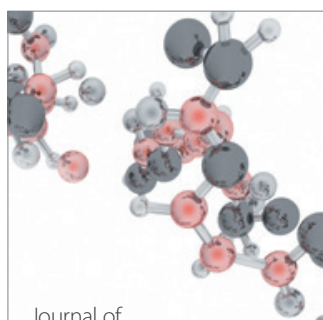

Analytical Methods

in Chemistry

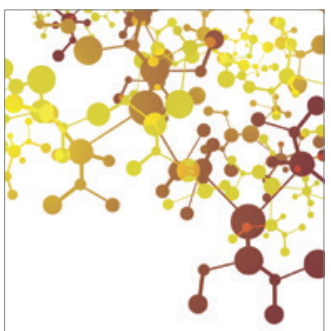

Journal of

Applied Chemistry

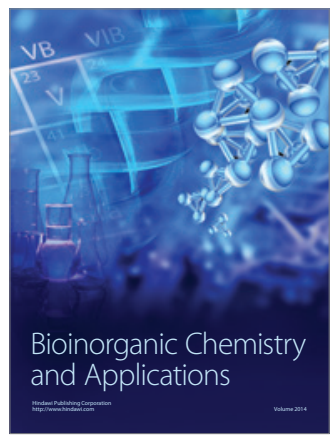

Inorganic Chemistry
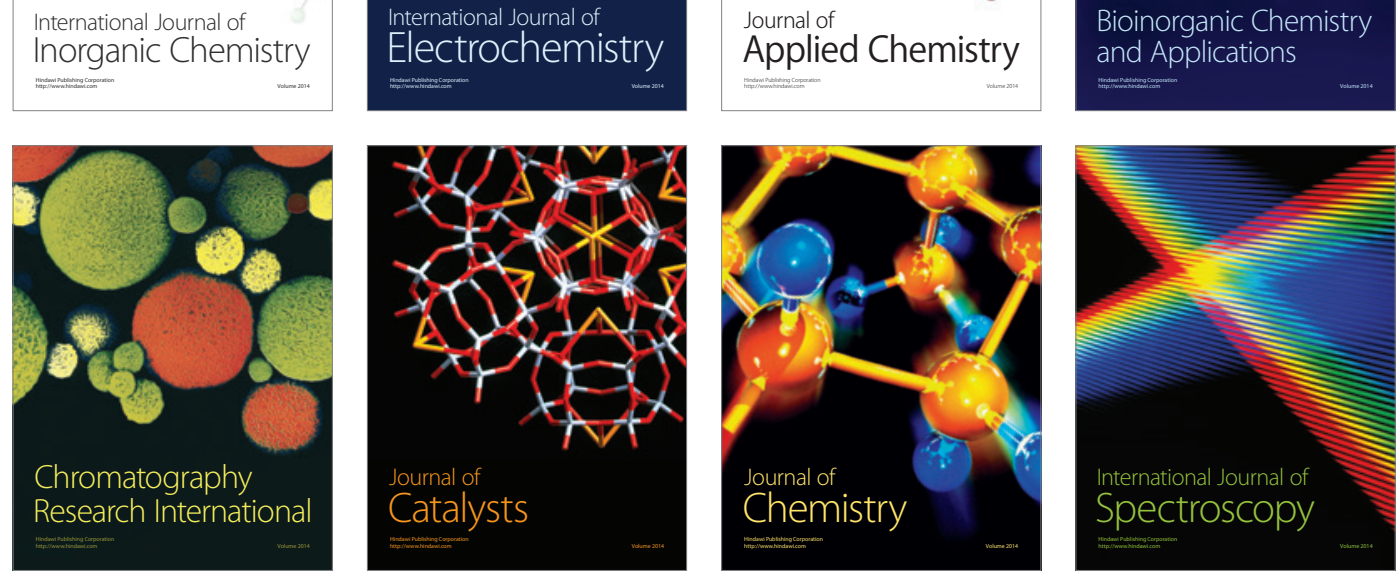